\title{
Publisher Correction: Regulation of cellular sterol homeostasis by the oxygen responsive noncoding RNA lincNORS
}

Xue Wu, Cristina M. Niculite, Mihai Bogdan Preda, Annalisa Rossi, Toma Tebaldi, Elena Butoi, Mattie K. White, Oana M. Tudoran, Daniela N. Petrusca, Amber S. Jannasch, William P. Bone, Xingyue Zong, Fang Fang, Alexandrina Burlacu, Michelle T. Paulsen, Brad A. Hancock, George E. Sandusky, Sumegha Mitra, Melissa L. Fishel (1D, Aaron Buechlein, Cristina Ivan (D), Spyros Oikonomopoulos, Myriam Gorospe,

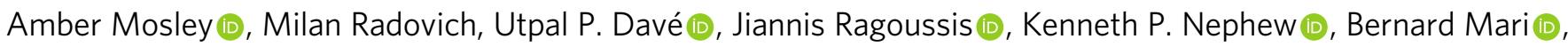
Alan Mclntyre (1), Heiko Konig, Mats Ljungman, Diana L. Cousminer, Paolo Macchi \& Mircea Ivan (1)

Correction to: Nature Communications https:/doi.org/10.1038/s41467-020-18411-x, published online 21 September 2020.

The original version of this Article contained an error in Fig. 7b, where the $p$ value for the association of the rs246185 SNP with MKL2 expression was accidentally copied during typesetting from the above panel, showing association with lincNORS, and incorrectly reported as $7.64 \mathrm{e}-7$. The correct $p$ value is $1.45 \mathrm{e}-1$.

This has now been corrected in both the PDF and HTML versions of the Article.

Published online: 06 November 2020

\footnotetext{
(c) Open Access This article is licensed under a Creative Commons Attribution 4.0 International License, which permits use, sharing, adaptation, distribution and reproduction in any medium or format, as long as you give appropriate credit to the original author(s) and the source, provide a link to the Creative Commons license, and indicate if changes were made. The images or other third party material in this article are included in the article's Creative Commons license, unless indicated otherwise in a credit line to the material. If material is not included in the article's Creative Commons license and your intended use is not permitted by statutory regulation or exceeds the permitted use, you will need to obtain permission directly from the copyright holder. To view a copy of this license, visit http://creativecommons.org/licenses/by/4.0/.
}

(C) The Author(s) 2020 